\title{
The versification of the Romansh poet Andri Peer: the heptasyllable and hendecasyllable in his early free forms
}

\section{Renzo Caduff}

\begin{abstract}
This paper examines the versification style of the Romansh poet Andri Peer, who can be considered as the first "modern" poet of the Romansh literature. It focuses on Andri Peer's most frequently used verse lines in his early free forms: the heptasyllabic and hendecasyllabic verse. A rhythmical analysis of the single verse instances revealed that the internal organisation of the line is not very elaborate. In the case of the heptasyllables found in his early free forms, only four patterns make up over $80 \%$ of all heptasyllabic verses. Regarding Peer's hendecasyllables, it is shown that his arrangement of the prominent syllables is rather regular, especially in comparison to the hendecasyllables of his precursor Peider Lansel. This trend in Peer's versification to use fixed dispositions of syllables is interpreted as a compensation for the loss of other structural features such as the stanza or the rhyme.
\end{abstract}

Keywords: heptasyllabic and hendecasyllabic verse; versification style; versi ombra; Romansh poetry

\section{Introduction}

Andri Peer (1921-1985) is one of the best-known poets of the Romansh language which is spoken in Switzerland, in the canton of Grisons ${ }^{1}$. Peer is often considered as the first "modern" poet of Romansh literature (Riatsch 2003: 492). He studied French and Italian literature in Zurich and Paris, where he met famous poets such as Eluard and became familiar with current trends in modern poetry, especially with the techniques of the vers libre. Peer was fascinated by the poetry of Eluard, Valéry, Eliot, Montale, Lorca and others but

* Author's address: Renzo Caduff, University of Geneva, Unité de rhétoromanche, Rue StOurs 5, CH-1205 Geneva, Switzerland; email: renzo.caduff@unige.ch.

1 The Romansh language is spoken by around 40000 (21.5\%) people in the canton of Grisons in Switzerland (Grünert et al. 2008: 26). It consists of five regional written varieties and rumantsch grischun, a standard variety created in 1982 (Anderson 2016: 169s.). Andri Peer wrote in Vallader, the Romansh variety of the Lower Engadine and the Val Müstair, which is spoken by around 5’300 native speakers (Roegiest 2006: 167). 
also deeply interested in traditional Romansh poetry, primarily in the works of Peider Lansel (1863-1943). Therefore, when analysing Peer's versification, various influences must be born in mind: Peer's Romansh roots, his interest in "modern" romance poetry, particularly French and Italian, as well as the exposure of the Romansh language and literature to the German-speaking culture.

In this contribution, Peer's specific use of the heptasyllable and hendecasyllable, the most frequently used verse forms in his early free forms shall be analysed. After discussing some characteristics of "traditional" Romansh metrics (section 2), the rhythmical patterns of the hendecasyllable used by Peider Lansel, Peer's major precursor, will be presented (section 3). Against this backdrop, Peer's use of the heptasyllable and hendecasyllable in the free forms of his early creative period (1946-1951) shall be examined (section 4 and 5). This will be done by analysing the rhythmical patterns of these two verse forms as well as by looking for so called versi ombra.

\section{Metrics in Romansh}

Until today, only a few studies on specific aspects of Romansh metrics have been published (Hartmann 1906 and 1908, Maxfield 1938, Fasani 1992-1993, Walther 1993 and Caduff 2010, 2013 and 2014). Nevertheless, it seems possible to define some fundamental principles of versification in Romansh. The specific situation of Romansh, a language in close contact with and strongly influenced by German and in earlier times by Italian ${ }^{2}$, demands that the German and Italian metrics must be considered when analysing Romansh verses. Moreover, some Romansh poets as for example Andri Peer may be influenced by their extensive reading of French poetry. Because of these variegated influences, it is to be assumed that in Romansh poetry different principles of versification are simultaneously existing on a synchronic level, while in other so called "national" literatures different principles of versification are generally detected when adopting a diachronic perspective. Analysing Romansh poetry thus means to consider the syllabo-tonic as well as the accentual-syllabic ${ }^{3}$ verse depending on the author in question (see Caduff 2014).

2 Particularly the two varieties of the Engadine are influenced by Italian.

3 See Menichetti: "Escludendo pochissime eccezioni, il principio che regge il verso italiano è sillabico-ritmico: il verso è cioè metricamente definito dal numero delle 'sedi' sillabiche che lo compongono e dal suo 'ritmo"'. (Menichetti 1993: 89) [italics in original]. 


\section{The hendecasyllable of Peer's precursor Peider Lansel}

An important influence on Andri Peer was the poetry of Peider Lansel, the classical poet of the Lower Engadine. An analysis of the verse system of Peider Lansel showed that he refers to the Italian endecasillabo (Caduff 2013) ${ }^{4}$. Lansel uses the traditional stress schemes of the most dominant form of Italian poetry, however, he does not use the synaloepha, which is an important metrical figure in Italian syllabics ${ }^{5}$. Thus, Lansel's metrics shows at least one original feature in comparison with Italian metrics.

Lansel's translation of the two initial verses of Giacomo Leopardi's La sera del di di festa (The Evening after the Holy Day), contrasted with the original, may illustrate Lansel's renunciation of the synaloepha ${ }^{6}$.

La sera del di di festa

Dolce $^{\wedge} \mathrm{e}$ chiara ${ }^{\wedge} \mathrm{è} \mathrm{la} \mathrm{notte}{ }^{\wedge} \mathrm{e}$ senza vento,

E queta sovra $\wedge$ i tetti ${ }^{\wedge} \mathrm{e}^{\wedge} \mathrm{in}^{\mathrm{mezzo}}{ }^{\wedge} \mathrm{agli}^{\wedge}{ }^{\circ}$ orti

(Leopardi 1998: 275s.)

La saira dal firà

Dutsch' e clêr' es la not e sainza vent

e quieta sur ils tets e sur ils jerts

(Lansel 1907: 74)

Evidently, Lansel uses the phonetic figure of the elision employing two apostrophes ("Dutsch' e clêr") in his translation of Leopardi's incipit?

The following examples show the metrical patterns of the hendecasyllabic verse used by Peider Lansel ${ }^{8}$. In his poems, he uses the three most predominant

\footnotetext{
4 In contrast to Lansel's verse form the versification of Zaccaria Pallioppi (1820-1873), another classical Engadine poet, corresponds to the syllabo-tonic system as it is used in German poetry (Caduff 2013: 297ss. and Caduff 2014: 74s.).

5 To the best of my knowledge, the synaloepha is hardly ever used in Romansh poetry, however, no study has focussed on this question so far.

6 I've indicated the synaloepha by the aid of the circumflex.

7 Surprisingly and by way of exception - as shown in Caduff (2013: 287) - Lansel opted in a second version of his translation for the use of a synaloepha "Teiv' i clêra^es la not i sainza vent" (1929: 160, v. 1).

8 All the examples derive from the epic poem Il vegl chalamêr (The Old Inkpot), which is written in endecasillabi sciolti (unrhymed hendecasyllables).
} 
metrical types (in Jakobson's terminology, "verse designs") ${ }^{9}$ - of the italian endecasillabo: 4.8.10., 6.10. and 4.7.10 ${ }^{10}$.

ir sco giarsun aint pro seis pin a Vnescha (v. 35)

Quel veider chalamêr cha tü m'hasch dat (v. 1)

Imprais ch'el ha, schi'l plü vegl dals mattuns (v. 32)
4.8.10.

6.10 .

4.7.10.

As Gasparov stated, the endecasillabo is strongly conditioned by two structurally important stressed positions: before the end of line and before the movable caesura with an obligatory stress on syllables four and/or six (Gasparov 1996: 122).

As can be seen in the following example, Lansel's hendecasyllables are characterized by different metrical patterns ("verse designs") and therefore also by a richness of different rhythmical patterns ("verse instances").

Iris florentina

“...Toscana gentile,

dove il bel fior si vede d'ogni mese".

Cino da Pistoia

Eu at perchür, o iris florentina,

tü possasch crescher suot il tschêl alpin,

gnind a flurir eir in nos ajer fin,

malgrà dschêtas i naivs da l'Engiadina

2. -3.6 .10 .

sco 'n la dutscha cuntrada florentina,

ingio tuot la cuttür' es ün zardin,

2. -3.6 .10 .

chi da tuottas saschuns, d'ün bel cuntin

3.6.8.10.

minchadi otras fluors i frütta pina.

3.-4.6.8.10.

Tü'm plaschasch per ta fuorm' i ta culur

mo plü perché, in la raisch zopada

tegnasch a tuots segret'üna savur.

In quai sumegliasch orm'inamurada

4.6.10.

9 Jakobson distinguishes between "verse design" and "verse instance" on verse level (Versebene) and between "delivery design" and "delivery instance" on recitation level (Vortragsebene) (Jakobson 1960: 364-367, and Donat 2007, s.v. Stufen der metrischen Abstraktion).

10 Additional stressed positions are not indicated, especially for the first hemistich. 
chi la felicitad da siamur

6.10.

aint il plü fop dal cour tegna serrada.

4.6. -7.10 .

(Lansel 1929: 45)

Since the caesura is movable and two stressed positions may immediately follow each other ("malgrà dschêtas", v. 4; "cour tegna", v. 14) a broad selection of stressed positions exists. These options make it possible for Lansel to make use of a great rhythmical variety in his poems. Against this backdrop of Lansel's hendecasyllables Peer's hendecasyllabic verse forms will be analysed below ${ }^{11}$.

\section{Andri Peer's versification}

Also in Andri Peer's versification, the endecasillabo plays an important role. Andri Peer mostly used the regular forms such as sonnets or poems in four or three line stanzas at the beginning of his writing period. For his later editions the heterometric poems (i.e. poems in free verse) are characteristic. While the regular verse forms may be analysed metrically and rhythmically, the free forms can be scanned for rhetorical structures ${ }^{12}$.

In this contribution, however, the focus shall be on the two verse units that Andri Peer used most, that is the heptasyllable and the hendecasyllable. Surprisingly, the heptasyllable and the hendecasyllable can not only be found in Peer's bounded forms, for example in his sonnets, but also in his poems written in vers libres or in "free metrics" (metrica libera), to use Mengaldo's terminology (1991). For Peer's early period of writing (1946-1951) even a preponderance of these two verse units in the free forms can be detected (see Caduff 2010: 154ss.).

In his seminal paper Questioni metriche novecentesche (1991) Mengaldo suggested that in Italian metrics free forms are characterised as follows:

11 For this analysis, the Italian terminology will be used. While the heptasyllable corresponds to the Italian settenario with an obligatory stressed $6^{\text {th }}$ metrical position, the hendecasyllable corresponds to the Italian verso principe, the endecasillabo, with a compulsory stress on the $10^{\text {th }}$ metrical position.

12 In the poem Stà (Summer) e.g. the use of parallel structures is evident, as well as the verticality that reminds us of the poems of Giuseppe Ungaretti. Stà (1969): "Blau / Blau / Manzinas / Tschêl / Uondas / cun craista // Pizza / Vadret / Il vent / Il lai / Teis ögls / Tia bocca / Teis cour" ("Blue / Blue / Branches / Sky / Waves / with crown // Mountains / Glacier / The wind / The lake / Your eyes / Your mouth / Your heart”). 
1) Perdita della regolarità e funzione strutturale delle rime, che restano eventualmente "effetti locali".

2) Libera mescolanza di versi canonici e non canonici: presenze anche massicce dei primi, endecasillabo compreso, ovviamente non spostano la questione.

3) Mancanza dell'isostrofismo, ma distinguendosene un grado debole (strofe di configurazione versale differente ma con lo stesso numero di versi) e uno forte (strofe anche di differenti dimensioni). (Mengaldo 1991: 35)

1) Loss of regularity and structural function of the rhyme, which may be used as "local effect".

2) Free combination of canonical and non-canonical verses: a massive presence of the first (i.e. canonical verses) obviously does not change the situation.

3) Absence of isostrophism, which can, however, be subdivided into a weak degree (heterometric stanzas, but with an equal number of verses) and a strong degree (stanzas of a different length).

For Peer's particular use of the two characteristic line units, the heptasyllabic and hendecasyllabic verse, point 2) is especially crucial which states that a free combination of canonical and non-canonical verse lines is an important criterion of free verse or metrica libera and that free forms may be characterised by an overuse of the same canonical lines as for example the use of heptasyllables or hendecasyllables. 
5. The heptasyllable and hendecasyllable: two characteristic line units in Andri Peer's early free forms

The following tables show the heptasyllabic and hendecasyllabic recurrences in Andri Peer's early free forms (see also Caduff 2010: 155s.):

Table 1. Recurrences of the 179 heptasyllables in Peer's early free forms ( $n=246$ )

\begin{tabular}{|l|l|r|}
\hline Patruglia (1946) & 16 of 20 lines & $80 \%$ \\
\hline Tea Room (1948) & 28 of 38 lines & $73.7 \%$ \\
\hline HBF (1948) & 46 of 63 lines & $73 \%$ \\
\hline Mezzanot (1948) & 25 of 30 lines & $83.3 \%$ \\
\hline Mumaint creativ (1948) & 49 of 54 lines & $90.8 \%$ \\
\hline Il sömmi (1951) & 15 of 41 lines & $36.6 \%$ \\
\hline
\end{tabular}

Table 2. Recurrences of the 80 hendecasyllables in Peer's early free forms ( $n=140$ )

\begin{tabular}{|l|l|r|}
\hline Uoss'est qua (1946) & 8 of 22 lines & $36.4 \%$ \\
\hline Aspet (1946) & 7 of 12 lines & $58.3 \%$ \\
\hline Femna (1948) & 7 of 9 lines & $77.8 \%$ \\
\hline Davomezdi (1948) & 32 of 51 lines & $62.7 \%$ \\
\hline I dà... (1951) & 19 of 26 lines & $73 \%$ \\
\hline Segns dascus (1955) & 7 of 20 lines & $35 \%$ \\
\hline
\end{tabular}

As can be seen in Tables 1 and 2 the heptasyllables (72.75\%) and the hendecasyllables (57.1\%) are very frequent in Peer's early free forms. In the following sections both an example of a predominant recurrence of a heptasyllable and of a hendecasyllable will be discussed. 


\subsection{The use of the heptasyllable in the poem Mezzanot}

A typical example of a free verse poem with a predominant use of heptasyllables is Mezzanot (Midnight). Table 3 gives an overview of the types of lines that are used in the poem.

Table 3. Lines in the different versions of Mezzanot

\begin{tabular}{|l|l|}
\hline publications & 1948; 1950a; 1951; 1954/55; 1955 \\
\hline stanzas or verse sections & 7 or 6 (1955) \\
\hline lines & 30 \\
\hline 9-syllable & 1 \\
\hline heptasyllable & 25 \\
\hline 6-syllable & 2 \\
\hline 5-syllable & 2 \\
\hline
\end{tabular}

In Midnight, there are only five lines that are not heptasyllabic. They all appear in the first two stanzas of the poem, at the beginning of the verse section, apart from the 9 -syllable in verse 9 .

$\begin{array}{lc}\text { Andri Peer, Mezzanot } & \\ & \\ \text { Sper la baselgia } & 5 \\ \text { cur chi batta l'ura } & 6 \\ \text { ed ün ventin da not } & 7 \\ \text { s'giovainta illa giassa } & 7 \\ & \\ \text { Cur cha sü ot las } & 5 \\ \text { quaidas nüvlas sömgian } & 6 \\ \text { e zoppan da la glüna } & 7 \\ \text { la sblacha ravaschia } & 7 \\ \text { nüvlas, o vus etern cumgià } & \text { '9 (or 2 + '7) } \\ \text { da sours chi partan leiv - } & \text { '7 } \\ \text { (Peer 2003 [1948], 28-29, v. 1-10) }\end{array}$

If the line breaks between the 5- and 6-syllables are removed, we obtain two hendecasyllables, the other predominant unit in Peer's free verse forms. 
lines 1-2 Sper la baselgia cur chi batta l'ura $\quad 11 \quad$ 4.(6.)8.10.

lines 5-6 Cur cha sü ot las quaidas nüvlas sömgian $11 \quad$ 4.6.8.10.

Interestingly, in one of the several unpublished versions of Mezzanot (Peer, Swiss Literary Archives, Berne, A-1-b/3) the lines 5-6 still formed a hendecasyllable.

Also, the lines 11 and 12 formed a classic French alexandrine.

Là stuna sainza pais

sün veidra salaschada

Là stun gugent sulet sün veidra salaschada

'7

7
13 (classic alexandrine)

However, when Peer published the poem in 1948, he split up the long verses. As Peer also used alexandrines in other poems (Caduff 2010: 185-190) it can be supposed that Peer's heptasyllable may sometimes also be a hemistich of an alexandrine. The rhythmical patterns of Peer's heptasyllables too show a similarity with the hemistich of an alexandrine.

The next 20 verses of Mezzanot are all heptasyllabic as an excerpt of the third stanza illustrates:

$\begin{array}{lcl}\text { Là stuna sainza pais } & \text { '7 } & 1 .-2.6 . \\ \text { sün veidra salaschada } & 7 & 2.6 . \\ \text { e taidl al cling dal sain } & ' 7 & 2.4 .6 . \\ \text { chi trembla illas lastras } & 7 & 2.6 . \\ \text { chi fa il gir dals vouts. } & ' 7 & 2.4 .6 .\end{array}$

An analysis of the single verse instances shows that the distribution of the stressed positions is quite regular and that the iambic stress pattern is most frequent. This regularity can be found throughout the heptasyllables of Peer's free forms, as the following table illustrates: 
Table 4. Rhythmical patterns of Peer's heptasyllable

\begin{tabular}{|l|l|r|}
\hline Rhythmical patterns of the heptasyllable & Frequency $(\mathrm{n}=179)$ & $\% \%$ \\
\hline 2. and 6. position & 74 lines & $41.3 \%$ \\
\hline 2., 4. and 6. position & 35 lines & $19.5 \%$ \\
\hline 4. and 6. position & 22 lines & $12.3 \%$ \\
\hline 1., 4. and 6. position & 17 lines & $9.5 \%$ \\
\hline 1. and 6. position & 7 lines & $3.9 \%$ \\
\hline 1., 3. and 6. position & 6 lines & $3.4 \%$ \\
\hline 3. and 6. position & 6 lines & $3.4 \%$ \\
\hline 6. position & 3 lines & $1.7 \%$ \\
\hline 2.-3. and 6. position & 5 lines & $2.8 \%$ \\
\hline 3.-4. and 6. position & 1 line & $0.6 \%$ \\
\hline 1., 3. -4. and 6. position & 1 line & $0.6 \%$ \\
\hline 1.-2. and 6. position & 1 line & $0.6 \%$ \\
\hline 1.-2., 4. and 6. position & 1 line & $0.6 \%$ \\
\hline
\end{tabular}

As Table 4 shows, only four different rhythmical patterns of the heptasyllable make up over $80 \%$ of all heptasyllables (Caduff 2010: 163s.). Thus, the verse unit, i.e. the number of syllables as such, is more important in Peer's versification than the internal rhythmical organisation of the line. This observation is also confirmed by an analysis of the hendecasyllabic verse in the following example.

\subsection{The use of the hendecasyllable in Segns dascus}

The poetological free verse poem Segns dascus (Secret signs) discusses the hiding places of poetry (see also Caduff 2014: 80s.).

$\begin{array}{ll}\text { Segns dascus } & \text { '9 } \\ \text { O vus povrets chi giais tscherchand } & 9 \\ \text { il zoppel da la poesia } & \text { '8 } \\ \text { nossa Diala culs ögls d'or } & 9 \\ \text { Lavai voss ögls illa funtana } & 9 \\ \text { perche els sun tuorbels da tschierpla } & 10 \\ \text { e boffai oura vossas uraglias } & \text { '8 } \\ \text { culs spagliaduors dal favuogn! }\end{array}$




$\begin{array}{lll}\text { Ingio avda la poesia } & 9 & \\ \text { scha na in ün crap dal flüm } & \text { '8 } & \\ \text { in ün dschember tschunc da la sajetta } & 10 & \\ \text { in ün svoul d’aglia tras il temp } & \text { '9 } & \\ \text { o illa sgrischida blonda d’üna früja } & 12 & \\ \text { in pail mulschin dad üna mür } & \text { '9 } & \\ \text { in ün recham da lichen sülla crappa } & 11 & 4.6 .10 . \\ \text { aint il sbriun d'ün’aua ravaschusa } & 11 & 4.6 .10 . \\ \text { chi squitta our'in sbrinzlas sa paschiun } & \text { '11 } & 2.4 .6 .10 . \\ \text { illa chavlüra bluorda da las flammas } & 11 & 4.6 .10 . \\ \text { cur chi uondagian tras ils giodens vöds } & \text { '11 } & 4.8 .10 . \\ \text { o illa nervadüra d’üna föglia } & 11 & 6.10 . \\ \text { chi’s placha sco ün man per benedir } & \text { '11 } & 2.6 .10 .\end{array}$

(Peer 2003 [1955], 83, v. 1-20)

For our argumentation, especially the second stanza is important. It begins with a rhetorical question about the whereabouts of poetry. The answers are for example "in the flight of an eagle through time" (v. 11), in a "lichen stitchery on a rock" (v. 14) or in the "veins of a leaf" (v. 19). Toward the end of the stanza, there is an accumulation of hendecasyllables. As can be seen above, the arrangement of the prominent or stressed syllables is quite regular in comparison with Peider Lansel's verse instances (see chapter 3). For Peer, the verse unit seems to be more important than the diversity of the rhythmical configuration. From this perspective, the unit resembles the French "décasyllabe", a unit that is predominantly determined by the number of syllables ${ }^{13}$.

As Peer's heptasyllable, the frequent recurrence of the hendecasyllable too can be seen as a kind of compensation structure for the absence of regularly used verse constituents such as the rhyme. Both verses, the heptasyllable and the hendecasyllable, can thus be considered as "ideal" verse units.

\footnotetext{
13 Frey states that "the French verse is basically determined by the number of syllables and thus much precarious [by the dissolution of the severe metrical laws] as the German, which depends on the accents", "Der französische Vers ist hauptsächlich durch die Silbenzahl bestimmt und dadurch viel prekärer als der deutsche, der von den Akzenten lebt" (2000: 34). See further Vaillant who speaks of a "faiblesse rythmique de la langue française" (2005: 259).
} 


\subsection{Verse segmentation as an evidence of "modernity" and the versi ombra}

Another feature of Peer's versification can be found in poems that may be categorised as "hybrid forms" (Caduff 2010: 144-153). These forms are characterized by different manifestations of dissolving verse entities such as a segmentation of verse into graphic lines, the abandonment of rhyme structure or a free combination of canonical and non-canonical verses. Their only common characteristic is the tension between verse level and delivery level ${ }^{14}$.

Listening to a recitation of the poem Lai Leman (Lake of Geneva) one might expect a segmentation into verses of 6 syllables each:

Sguonda tia staila,

uonda, alba vaila.

Vigna, god, chastè

fan al lai anè.

Follow your star, wave, white sail.

Vineyard, wood, castle are circle to the lake.

However, Peer's poem is not written in bounded verses: instead he chose the following segmentation, that is reminiscent of the verticality of "modern" poetry such as the poems of Giuseppe Ungaretti.

\section{Lai Leman}

Sguonda

tia staila,

uonda,

alba vaila.

Vigna,

god,

14 For the opposition between the German "Vers-" and "Vortragsebene" see also Küper (1988) and Donat (2010). 
chastè

fan

al lai

anè.

(Peer 2003 [1975], 253)

This example of a hybrid form shows Peer's playful handling of the segmentation of verse; i.e. he graphically blurs the bounded form by segmenting the poem as a free form (see also Caduff 2010: 144-153).

In Peer's poetry, further dissimulated units or versi ombra (Menichetti 1993: 151ss.) can be detected. An example which shows an interesting interrelation between form and content is the poem Retuorn (Return). The poem's topic is already subsumed in the title, Return. In Romansh poetry, the motives of leaving and returning are emblematic moments, especially in the poems of the so called "randulins" ${ }^{15}$. The return of the emigrant to the Engadine of his childhood also is an important motive in Andri Peer's literary work.

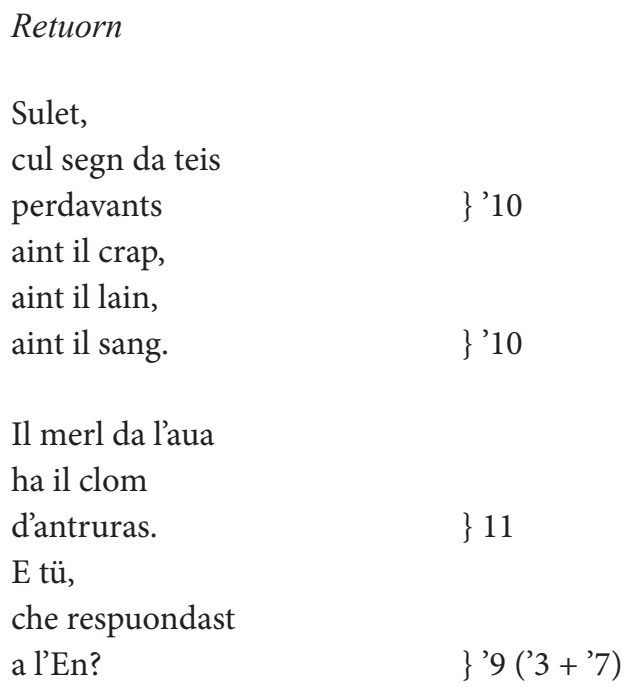

(Peer 2003 [1975], 273)

15 The term "randulins" (from randulina, Engl. 'swallow') is used for the Engadine emigrants who often worked as confectioners in different parts of Europe, especially in Italy and France. During the summer season, they usually returned to their native villages for holidays. 
Return

Alone,

with the sign of your

ancestors

in the stone,

in the wood,

in the blood.

The dipper

has his former

call.

And you,

what do you answer

to the Inn?

Alone with the sign of his origin, the remigrant seems to be confronted with the reproachful question of the river $\operatorname{Inn}^{16}$, why he left his homeland and, in doing so, his native tongue as well ${ }^{17}$. The comparison of the remigrate, addressed as a "you", with the dipper (v. 7-9), which in contrast did not change its former call, may be interpreted as a sign of a bad conscience of the repatriate who lives and works in a German-speaking region.

Regarding the structure of the poem, particularly the first stanza is worth mentioning. The fact that all verse lines end with a word stressed on the final syllable highlights the enumeration "in the stone", "in the wood" (i.e. in the Engadine houses) and "in the blood" and thus the loneliness of the repatriate. The strong enjambement "teis / perdavants", which separates the trisyllabic "perdavants" from the possessive pronoun, further intensifies the subsequent climax "aint il crap, / aint il lain, / aint il sang".

While the first verse section seems to be mainly organised by the parallelistic enumeration "in the stone, / in the wood, / in the blood", the second section is composed by two phrases. By removing the line breaks, the following lines can be recomposed:

16 In the precedent tradition instead of a question the Inn welcomes the repatriate, e.g. Peider Lansel, Vuschs da la patria (Voices of fatherland): "Binsan!... Binsan!... cun vusch cuntschainta / salüda l'En tras l'ota pasch -", "Welcome!... Welcome!... with a well-known voice / the Inn greets through the high peace -” (1966: 41, v. 1-2).

17 Peer himself had left his native valley to work as a secondary school teacher in the Germanspeaking part of Switzerland. 
Il merl da l'aua ha il clom d'antruras.

11

E tü, che respuondast a l'En?

'9 ('3+'7)

Obviously, the first verse is a hendecasyllable, a verse form which Peer often uses in his early free forms (cf. Table 2 and section 5). From a poetic point of view, the "former call"18 of the dipper could be interpreted as reference to Peer's frequent use of the hendecasyllabic unit in his early poetry. Thus, there is an analogy between content and form: the poet who "returns" to his earlier tracks by using a camouflaged hendecasyllabic line.

Regarding the content, the use of the adverb antruras ('in former times' from Lat. ALTERAM HORAM) that does not exist in Peer's variety of Romansh, Vallader, but is borrowed from the Sursilvan variety (see Caduff 2010: 187s.) can be read as an allusion to a primary state when the Romansh language was not yet divided into five regional written varieties. Hence, the poem Retuorn is on the one hand a return to the Engadine, not least for the poet, but on the other hand also a return to a former use of language and verse ${ }^{19}$.

\section{Conclusion}

As pointed out in section 5 (Table 1 and 2), Andri Peer uses in many of his free verse poems of the first period (1946-1951) a significant number of the same verse lines, either the heptasyllable or the hendecasyllable. According to Mengaldo, this use illustrates a free combination of canonical and noncanonical verse lines and corresponds to one of Mengaldo's three criterions of free metrics (metrica libera) (section 4).

18 See in this context Giovanni Pascolis poem Addio!: "quando ascolto voi [le rondini] parlar tra voi / nella vostra lingua di gitane, / una lingua che più non si sa", Goodbye!: "when I listen to you [the swallows] speaking to each other / in your gypsy tongue, / a language which one does not know anymore" (Pascoli 1931: 176, v. 16-18).

19 Similar to the proceeding in the poem Return, in the poem Furnatsch (2003 [1960], 122) too it is possible to recompose a hendecasyllable by removing the line breaks: "Immez sbodats / Cluchers da las / Sumbrivas", "Among broken down / Towers of the / Shadows" (v. 64-66). From a metrical perspective, the towers that are broken down could also be read as a 'broken down' hendecasyllable. Such a reading fits with the verse structure of the poem Furnatsch, whose 66 verses correspond to 8 different verse lines: 9-syllable (5 lines), 8-syllable (13), heptasyllable (13), 6-syllable (12), 5-syllable (19), 4-syllable (2), 3-syllable (1) and 2-syllable (1). Thus, the hendecasyllable as a primary structural entity of Peer's early free forms (cf. section 5) has lost its structural function and at the same time points to a new segmentation technique. 
A rhythmical analysis of the single verse instances revealed that the internal organisation of the line is not very elaborate. More specifically, the analysis of the rhythmical patterns of Peer's heptasyllable showed that only four patterns (2. and 6. position; 2., 4. and 6. position; 4. and 6. position; 1., 4. and 6. position) make up over $80 \%$ of all heptasyllables (section 5.1). For the rhythmical organisation of Peer's hendecasyllables, it was shown that his arrangement of the prominent syllables is quite regular, especially in comparison to the hendecasyllables of his precursor Peider Lansel (section 5.2). Therefore, we may conclude that in Peer's versification the verse unit is more important than the rhythmical pattern. Instead of rhythmical patterns, Peer uses other means of structuring, especially the frequent repetition of the same verse line. Thus, he creates a sort of alternative structure to compensate for the absence of structural features such as the stanza or the rhyme. In other words: there is only weak or no "rhythmical arrangement" within the line, as Peer focuses on structuring larger rhythmical sequences by using equal lines, especially the heptasyllable and hendecasyllable.

Analysing the segmentation of verse into graphic lines in Peer's hybrid forms and in his later poetry, dissimulated units or versi ombra could be detected (section 5.3). An example of such a hidden hendecasyllable can be found in the poem Retuorn which shows that the hendecasyllable can still "return", camouflaged as a modern verse segmentation.

Both verse forms, the heptasyllable and the hendecasyllable, may therefore be considered "ideal" verse units, especially in Peer's early free forms (1946-1951). Possibly, Peer had internalised basic units deriving from his extensive reading of Italian (endecasillabo) and French poetry (alexandrin) which, however, he segments into smaller lines in order to follow a more vertical segmentation. 


\section{References}

Anderson, Stephen R. 2016. Romansh (Rumantsch). In: Ledgeway, Adam; Maiden, Martin (eds.), The Oxford Guide to the Romance Languages. Oxford: Oxford University Press, 169-184.

Caduff, Renzo 2010. Die Metrik Andri Peers im Spannungsfeld zwischen bündnerromanischer Tradition und europäischer Moderne. Dissertation Freiburg $(\mathrm{CH})$, 2010. doc.rero.ch/record/27018.

Caduff, Renzo 2013. Die Verskunst Peider Lansels am Beispiel des Elfsilblers. In: Darms, Georges; Riatsch, Clà; Solèr, Clau (eds.), Akten des V. Rätoromanistischen Kolloquiums / Actas dal V. Colloqui retoromanistic (Lavin 2011). Tübingen: Francke, 283-302.

Caduff, Renzo 2014. Bündnerromanische Metrik am Beispiel dreier Engadiner Lyriker: eine hybride Kombination metrischer Einflüsse der Nachbarliteraturen? In: Haupt, Sabine (ed.), Tertium Datur! Formen und Facetten interkultureller Hybridität. Berlin: LIT Verlag, 69-84.

Donat, Sebastian 2007. Literaturwissenschaftliche Grundbegriffe online. Metrik. www.li-go.de (3.1.2017).

Donat, Sebastian 2010. Deskriptive Metrik. Innsbruck: Studienverlag.

Fasani, Remo 1992-1993. Metrica di Peider Lansel, metrica romancia e traduzione della “Commedia”. In: Quaderni grigionitaliani 61(4), 298-313; 62(1), 13-30; 62(2), 101-109.

Frey, Hans-Jost 2000. Verszerfall. In: Vier Veränderungen über Rhythmus. Basel: Engeler, 7-84.

Gasparov, Mikhail L. 1996. A History of European Versification. Oxford: Clarendon Press.

Grünert, Matthias et al. (eds.) 2008. Das Funktionieren der Dreisprachigkeit im Kanton Graubünden. Tübingen, Basel: Francke.

Hartmann, Gottfried 1906. Neuere Lyrik in Graubünden. Sonderabdruck aus "Festschrift zum 12. Deutschen Neuphilologentag 1906”. Erlangen: Junge \& Sohn, 475-498.

Hartmann, Gottfried 1908. Zur rätoromanischen Verskunst. In: Festschrift Philologische und Volkstümliche Arbeiten. Erlangen, 287-294.

Jakobson, Roman 1960. Linguistics and Poetics. In: Sebeok, Thomas A. (ed.), Style in Language. Cambridge, Mass.: The M.I.T. Press, 350-377. 
Küper, Christoph 1988. Sprache und Metrum. Semiotik und Linguistik des Verses. Tübingen: Niemeyer.

Lansel, Peider 1907. Primulas. Prümas rimas et versiuns poeticas, nova ediziun. Ginevra: Atar.

Lansel, Peider 1929. Il vegl chalamêr. Poesias da Peider Lansel, Ediziun definitiva. Zürich: Fretz.

Leopardi, Giacomo 1998. La sera del dì di festa. In: Gavazzeni, Franco (ed.), Giacomo Leopardi, Canti. Milano: Rizzoli.

Maxfield, Mildred Elizabeth 1938. Studies in Modern Romansh Poetry in the Engadine with special consideration of Zaccaria Pallioppi (1820-1873), Gian Fadri Caderas (1830-1891) and Peider Lansel (1863 - - ). Cambridge: Massachusetts.

Mengaldo, Pier Vincenzo 1991. Questioni metriche novecentesche [1988]. In: La tradizione del Novecento. Terza serie. Torino: Einaudi, 27-74.

Menichetti, Aldo 1993. Metrica italiana. Fondamenti metrici, prosodia, rima. Padova: Antenore.

Pascoli, Giovanni 1931. Canti di Castelvecchio. Milano: Mondadori.

Riatsch, Clà 2003. Aspets da l'ouvra poetica dad Andri Peer. In: Riatsch, Clà (ed.), Andri Peer, Poesias (1946-1985). Cuoira: Desertina, 485-526.

Roegiest, Eugeen 2006. Le rhéto-roman. In: Vers les sources des langues romanes. Un itinéraire linguistique à travers la Romania. Leuven: Acco, 166-178.

Vaillant, Alain 2005. Pour une poétique du vers syllabique. In: Poétique 143, 259-281.

Walther, Lucia 1993. Der Umgang mit traditionellen Formen - das Sonett. In: Riatsch, Clà, Walther, Lucia (eds.), Literatur und Kleinsprache. Studien zur bündnerromanischen Literatur seit 1860, Romanica Raetica 11. Chur: Società Retorumantscha, 211-235. 